Journal of Education and Vocational Research

Vol. 3, No. 2, pp. 48-57, Feb 2012 (ISSN 2221-2590)

\title{
Vipassana Meditation and Life Effectiveness
}

\author{
Dileep Kumar. M. \\ Othman Yeop Abdullah Graduate School of Business (OYA-GSB), Universiti Utara Malaysia, Malaysia \\ dileep@uum.edu.my
}

\begin{abstract}
Vipassana Meditation among business managers who did Vipassana Meditation during their management education or after. How far Vipassana Meditation process influences life effectiveness of these young managers. Quantitative-multidimensional analysis of attitudinal and behavioral variables is the primary focus of this study. Exploratory study is conducted to arrive at appropriate variables in relation the professional and personal dimensions selected for the study. Data collection made from 176 junior level managers, who have passed out from five business schools in Pune, India. Independent and dependent variables are analyzed into with correlation and multiple regression models. The findings indicate that the Vipassana meditation process is having high influence on professional and personal effectiveness of managers. This research study envisages the importance of holistic education to the management graduates that ensure the development of physically stable, mentally alert and professionally matured students for better operations and business excellence.
\end{abstract}

Keywords: Mediation, Life Effectiveness, Managers, Holistic Education

\section{Introduction}

Education is a continuous and creative process. The aim of education is to realize the innate qualities, potentials and talents of individuals and to develop these capacities latent in human nature to get personalsocial satisfaction and enrichment and progress of society. True education helps individuals to understand their innate qualities and enable him to become self-motivating agent of social change, serving the best interests of the society. It is the fundamental premises that the young generation should take up the responsibility of their own development and for the nation by participating in the adventure of exploring and understanding their own creativity and intelligence through the process of education. But great tragedy here is the system of imparting formal education, under the four walls of a class room setting, through literature, lecture and library, putting no effort to make individual human being realize their creativity and potential, is now more concerned with immediate need satisfaction rather than materializing the long term cherished dreams of a nation. In the systematic process of building a new world order, their role becomes limited and far away from strategic thinking, creative decision-making and advancement of a civilization.

In this context Krishnamurti Foundation, (1992) rightly indicates that "At its best, the modern educational system imparts some professional knowledge and skills, but it lacks any cultivation of heart. The result is only to make the students conceited materialists. Consequently, at an age when children should be dreaming of beauty, greatness and perfection, they now dream about sensory titillation and wealth, and spend time worrying about how to earn money. Major problem we can identify here is the sharp deviation from the principle and aims of education in its perception and implementation in the modern social system. Although economic considerations are recognized as necessary to individual existence the objective of earning money through any means and accumulating wealth using any strategies, serves only individuals own short-term goal than long term one. Development of human resource through education should concentrate more on constructive value based holistic education than formal classroom education. Dhar (2003) in this context indicates that education should be concerned with the totality of life and not with immediate responses to immediate challenges. Broadly speaking, four different but inter-related aspects of human life can generally be recognized: viz., the physical, emotional, intellectual and spiritual. Holistic education should cultivate all these aspects in full measure. 


\title{
2. Literature review
}

Vipassana is an ancient meditation technique rediscovered by Gotama the Buddha, about 2500 years ago. It is currently being taught in India and several other countries under the guidance of Goenka, the principal teacher of Vipassana. It promotes conscious lifestyle changes, enhances concentration of mind and facilitates deeper psychological introspection to bring about lasting behavioral changes. Vipassana is a Pali word meaning "insight". It is a system of self-transformation by self-observation; the object is to eventually reach a state of inner and outer calmness and balance of mind (Thray, Sayagyi \& Ba, 1983).

\author{
Objectives of Vipassana \\ - $\quad$ To purify the mind. \\ - $\quad$ Brings about the total transformation of the human personality.
}

Vipassana meditation can be described as a technique of purifying the mind of its baser instincts so that one begins to manifest the truly human qualities of universal goodwill, kindness, sympathy, tolerance, humility, equanimity, etc., and simultaneously gains an insight into the true nature and purpose of human existence. This is achieved in a very scientific manner through a systematic cultivation of Right Mindfulness coupled with non-reactivity; that is to say, development of the habit of paying penetrating attention to whatever is happening in our total organism-the body with its five senses and the mind, which operates in and through itwithout any admixture of subjective judgments or reactions. The quality, which purifies the mind at the deepest level, is the mental factor of objectivity, or equanimity, which develops from the constant, thorough understanding of the impermanence of all components of the mind-body phenomenon (VRI, 1991).

\section{The characteristic features of Vipassana meditation:}

- It is a universal technique, which can be practiced by anyone belonging to any country, caste or creed.

- It strikes at the roots of our defilements in the unconscious mind and breaks the barrier between the conscious and unconscious layers of the mind.

- There is no place for imagination in this technique, no verbalization of any mantra or visualization of any god or goddess, or any other object. The practice starts from experience of the apparent truth of body and mind and proceeds towards realization of the subtle and absolute Truth.

- It is a highly individualistic and experiential method of meditation. Man must walk on the Path himself. No one else can make the effort for him or liberate him from the impurities of the mind. Hence, there is no "gurudom" in this technique.

- One reaps the benefits of this technique here and now, as one progressively becomes a better individual (Usha, 2000).

Effect of Vipassana: Venerable (1962) indicates the systematic practice of Anapana for a few days, the concentration increases, and a natural calming and equalizing of the breath takes place. As the breath is very intimately related to the mind, this leads simultaneously to a tranquilizing of the mind-in fact, of the entire life-rhythm. The practice of Vipassana consists of "feeling" the sensations throughout the body without any reaction or evaluation whatsoever, thus developing equanimity at a very deep level. This is of course more easily said than done, because our subconscious mind, which is constantly "feeling" the body sensations, has the stubborn, recalcitrant habit of reacting to these sensations in a particular manner. It habitually reacts to pleasant sensations with craving and to unpleasant sensations with aversion, thus strengthening the mind's conditioned tendency to run after sensory pleasure and to run away from pain (VRI, 2003).

Vipassana meditation trains the concentrated attention to follow the mechanics of mental processing in a detached fashion. This perspective of an observer allows the controlled release of mental contents like craving and aversion, past and future in a seemingly endless stream of memories, wishes, thoughts, conversations, scenes, desires, dreads, lusts and thousands upon thousands of emotionally driven pictures of every kind-which rise to the surface of the mind and pass away without provoking a reaction, while simultaneously anchoring one in concrete, contemporary reality (Fleischman, 1986). Since the mediator is at 
the same time deeply relaxed, the whole contents of his mind can be seen as composing a "Desensitization hierarchy"; in this sense, Vipassana meditation may be natural global self-desensitization (Goleman, 1977). The mind is deconditioned with meditation altering the process of conditioning per se, so that it is no longer a prime determinant of future acts (Goleman, 1977); a refinement of awareness occurs and one responds consciously to life situations thereby becoming free from limitations, which were forged by mere reactions to them. One's life becomes characterized by increased awareness, reality-orientation, non-delusion, self-control and peace (Fleischman, 1986). Such a person attains a state of inner and outer calmness and is able to make quick decisions, correct and sound judgment and concerted effort-mental capabilities, which definitely attribute to success in contemporary life.

Dhar (2003) indicates that the practice of Vipassana consists of "feeling" the sensations throughout the body without any reaction or evaluation whatsoever, thus developing equanimity at a very deep level. This is of course more easily said than done, because our subconscious mind, which is constantly "feeling" the body sensations, has the stubborn, recalcitrant habit of reacting to these sensations in a particular manner. It habitually reacts to pleasant sensations with craving and to unpleasant sensations with aversion, thus strengthening the mind's conditioned tendency to run after sensory pleasure and to run away from pai. The technique of Vipassana is a simple, practical way to achieve real peace of mind and to lead a happy, useful life. Vipassana means "to see things as they really are"; it is a logical process of mental purification through selfobservation (VRI, 2003). The technique of Vipassana is a path leading to freedom from all suffering; it eradicates the craving, aversion and ignorance, which are responsible for all our miseries. Those who practice it remove, little by little, the root causes of their suffering and steadily emerge from the darkness of former tensions to lead happy, healthy, productive lives (VRI, 2003).

Vipassana enables us to experience peace and harmony: it purifies the mind, freeing it from suffering and the deep-seated causes of suffering. The practice leads step-by-step to the highest spiritual goal of full liberation from all mental defilements (VRI, 2003). One student reported that during his stormy adolescent years he had acute differences of opinion with his parents. He left his parental home in great anger, never to see them again. He had not seen them for nearly ten years in spite of their several attempts to contact him. When he came for a Vipassana course, his ego began to dissolve and he began to perceive his own shortcomings. He felt extremely miserable, but was able to consider his parents' point of view. He was able to see the situation from different angles, and not only through his coloured glasses. He decided to write to his parents and tell them of his whereabouts, return home and talk it over with them (Usha, 2000). Nichani (2003) indicates that as one gets more and more established in the practice of meditation, there are fewer mental problems, and even psychosomatic disorders like hypertension, peptic ulcer, irritable bowel syndrome, asthma and eczema get ameliorated. Vipassana meditation, therefore, leads to better health and a happy, blissful mind.

There is less mental tension and confusion, and with such a clear and calm mind, one is able to deal easily with one's problems, thus living a merry and joyful life. Usha (2000) indicates that apart from the purification of the mind, which is the primary goal of the technique, the mediator also experiences gains at the physical and psychological level. Many common ailments such as hypertension, headaches, ulcers, acidity, etc., are very often psychosomatic. These are automatically cured as a by-product of the cleansing process of Vipassana. Usha (2000) further indicates that 'many students, who practice Vipassana regularly, keep reporting that their concentration, memory and ability to grasp the material they read have improved tremendously. One student who had given up his college studies midway and was on tranquillizers is now free of pills. He went back to his studies and has now completed them'.

Vipassana and business: Jayantilal (2003) indicated The Vipassana meditation technique improves the lives of executives and business managers by transforming their attitudes. Prejudice is replaced by compassion; jealousy changes into joy at the success of others; greed and arrogance are replaced by generosity and humility, and so on. This transformation of attitude results in stress reduction, and mental equanimity and balance. It is a creative force capable of inducing a dynamic work approach in subordinate staff. The positive change is brought about by a change in the attitude and actions of the executive-to polite and compassionate behaviour, gentle speech, and a mind full of love and friendliness. This positive change in consciousness is the aim of genuine meditation practice, and it forms a new and advanced basis for business and industrial management Jayantilal (2003) indicate further that Business management is presently judged by profits or 
"money-making" ability. Managers are evaluated by their ability to make more money by increasing product turnover, developing new technologies with better pay-offs, or decreasing costs through new inventions. In return, they want higher salaries and more requisites. Although there is nothing inherently wrong with generating profits and an increase in incomes, the real aim of an economic venture is to create a wealth, which combines money with health and happiness. Vipassana makes a significant contribution towards improving the mental health and happiness of individuals-vital components of wealth. Jayantilal (2003) indicates further One of the parameters in HRD process is the development of mutual respect, which naturally improves interpersonal relations. Meditation will also help to achieve this, enabling us to overcome the hostility towards fellow human beings- colleagues, subordinates, superiors, government officers and others. This hostility manifests as anger, arrogance, jealousy, vengeance, selfishness, greed, prejudice and ill will.

\section{Methodology}

Rationale of the study: The present day educational system more concentrates on classroom formal education rather than extending holistic educational experience to the students. It makes the individual more towards unstable development than ensuring sustainable development. Educational system has the major responsibility to ensure psychosocial, physical and spiritual development of the individual and the society. Since the students of present generation are expected to be the leaders of the coming era, it is necessary to extend holistic education to improve their self-realization and purification of mind. Many Business Management students' schools expose their students to Holistic Education Programs (Vipassana Meditation) to improve their attitude, perception, aptitude and sharpen personal and professional goals that ensure individual growth towards better social and sustainable development. The present study is aimed at understanding the influence of Vipassana Meditation on student's life effectiveness, especially, professional psychological and physical development.

\section{Objectives:}

- To understand the important understandings from Vipassana Meditation.

- To analysis, the relationship between Vipassana Meditation Process and life effectiveness among business graduates in their professional and personal life.

- To analysis, the influence of Vipassana Meditation Process on life effectiveness among business graduates in their professional and personal life.

- To analysis the moderating of socio-demographic factors on life effectiveness after Vipassana Meditation Process.

\section{Hypothesis}

H1: Vipassana meditation process may significantly relate to the life effectiveness among business management graduates in their professional and personal life.

H2: Vipassana meditation process may significantly influence the life effectiveness of business management graduates in their professional and personal life

H3: The socio-demographic (age, gender and employment) variables may have moderating effect on Vipassana Meditation process and life effectiveness of business management graduates in their professional and personal life.

Sampling frame: The universe selected for this particular research includes the students completed their education in five business schools in Pune city, India. The study considered 176 Business Management graduate students who completed their business management education from different business schools like Symbiosis Centre for Management and HRD, Indira School of Management, Indian Institute of Modern Management, Sadhana Centre for Management and Leadership Development and Sinhgad Business Schools and they are working in corporate into the functional levels as junior managers. These passed out students have undergone Vipassana meditation, in their academic career and after their academic course period. 176 managers covering 19-30 ages group who had successfully undergone the 10 days and one month Vipassana Meditation Course are considered for the data collection. These past students are now working in industries as managers in marketing, finance, operations IT and Human Resource functional area. All mangers are junior 
level managers. The study followed proportionate probabilistic sampling method for arriving at a representative size of the population. The population consists of both male and female students (managers).

4. Results and Analysis

Table 1: Measuring and categorizing compensation factors

\begin{tabular}{|c|c|c|c|}
\hline $\mathbf{S} / \mathbf{N}$ & Independent variables & Sub Factors & Scores and Values \\
\hline \multirow[t]{21}{*}{1} & Psychological & Peace and stability of mind & 0.811 \\
\hline & & Calm and composed & 0.801 \\
\hline & & Relaxation & 0.815 \\
\hline & & Understand strength and Weaknesses & 0.800 \\
\hline & & Patience & \\
\hline & & Compassionate & 0.821 \\
\hline & & Determined & 0.810 \\
\hline & & Confidence & 0.799 \\
\hline & & Feeling of equanimity & 0.780 \\
\hline & & Positive thinking & 0.799 \\
\hline & & Objective out look & 0.821 \\
\hline & & Intellectually refined & 0.810 \\
\hline & & Higher level of happiness & 0.802 \\
\hline & & Manage tension & 0.830 \\
\hline & & Manage anger & 0.822 \\
\hline & & Control Reactions & 0.834 \\
\hline & & Control Hyper activeness & 0.799 \\
\hline & & Reduce stress & 0.841 \\
\hline & & & 0.801 \\
\hline & $\%$ of variance explained & & 0.203 \\
\hline & Cronbach $\alpha$ & & 0.824 \\
\hline \multirow[t]{12}{*}{2} & Physical & $\begin{array}{l}\text { Understand one's own hidden strength } \\
\text { and potential }\end{array}$ & 0.800 \\
\hline & & Feel healthy and fresh always & 0.801 \\
\hline & & Aware of healthy diet & 0.822 \\
\hline & & Early wake up and early bed Habit & 0.831 \\
\hline & & attained & 0.845 \\
\hline & & Better health & 0.821 \\
\hline & & Decreased illness & 0.832 \\
\hline & & Body relaxation & 0.833 \\
\hline & & Physically organized & 0.841 \\
\hline & & Healthy psycho somatic relationship & 0.801 \\
\hline & $\%$ of variance explained & & 0.222 \\
\hline & Cronbach $\alpha$ & & 0.820 \\
\hline \multirow[t]{15}{*}{3} & Professional & Diligence at work & 0.818 \\
\hline & & Persistent at work & 0.820 \\
\hline & & Time management at work & 0.861 \\
\hline & & Focused at work & 0.833 \\
\hline & & Positive outlook on & 0.799 \\
\hline & & Objectivity in actions & 0.800 \\
\hline & & Being good with everybody at work & 0.812 \\
\hline & & Control of tension at work & 0.824 \\
\hline & & Control agitation at work & 0.831 \\
\hline & & Control anger at work & 0.825 \\
\hline & & Control of frustration at work & 0.833 \\
\hline & & Effective reaction management & 0.829 \\
\hline & & Stress management & 0.840 \\
\hline & & Value of Equanimity & 0.798 \\
\hline & & Rationale decision making & 0.789 \\
\hline
\end{tabular}




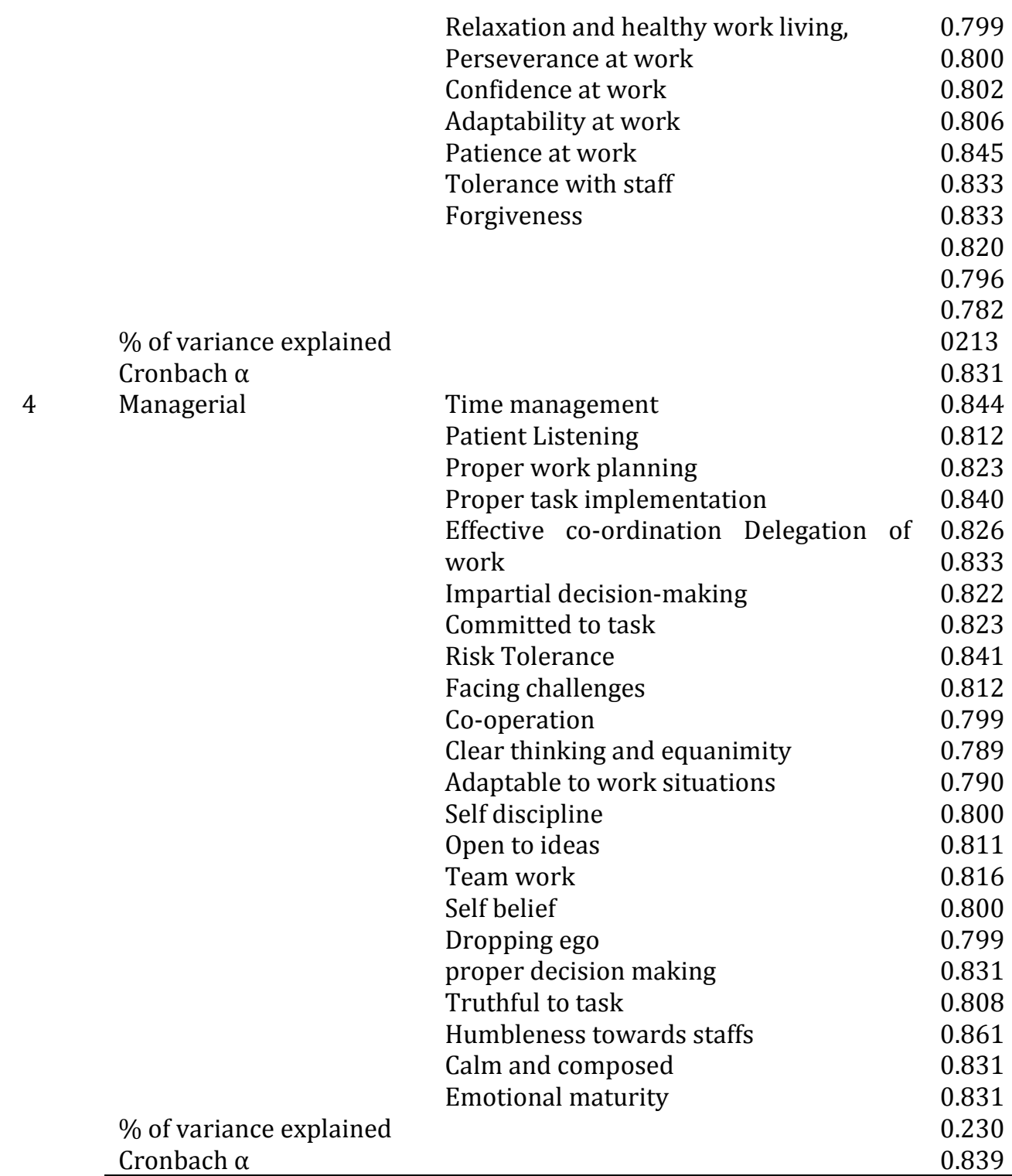

All the 10 factors (F1, F2, F3, and F4) that included in factor analysis were found most vital in coping pattern explaining 0.203, 0.222, 0.213, and 0.230 of the variance respectively. Thus, all the factors (Psychological, Physical, Professional and Managerial) are then considered for further analysis.

Measurement of validity and reliability of Vipassana process: The study did the content analysis by making use of extensive literature and previously validated constructs. It establishes further the incorporation of the representativeness of the items in the questionnaire, for adequate data collection. The questionnaire was pilot tested with 40 students who passed out from 5 post graduate business management institutions from Pune, India. 8 passed out students from each institution randomly selected (proportion based on business functions) to arrive at the reliability of the construct. The Cronbach Standardized Alpha was estimated to assess the reliability of the items selected for the study. As the relationship varied from 0.78 to 0.86 , the reliability test passed. All the items in the questionnaire have secured reliability score above .60 and thus all the items were considered for the study. 
Table 2: Validity and Reliability of Vipassana Process

\begin{tabular}{|c|c|c|c|c|c|c|c|}
\hline $\mathbf{S} / \mathbf{N}$ & $\begin{array}{l}\text { Sub Variables } \\
\text { Vipassana Proce }\end{array}$ & & Construct & $\mathbf{M}$ & $\mathbf{A}$ & $\begin{array}{l}\text { \% of Var } \\
\text { explained }\end{array}$ & $\begin{array}{l}\text { Factor } \\
\text { Loading }\end{array}$ \\
\hline \multirow[t]{7}{*}{1} & \multirow{7}{*}{\multicolumn{2}{|c|}{ Watching the belly }} & Focusing our attention on the & 9.33 & 0.83 & 75.5 & 0.87 \\
\hline & & & $\begin{array}{l}\text { Breathing process felt around the } \\
\text { belly }\end{array}$ & & & & 0.80 \\
\hline & & & Watching this belly movement & & & & 0.87 \\
\hline & & & Controlling the thoughts & & & & \\
\hline & & & $\begin{array}{l}\text { Thoughts gradually started } \\
\text { disappearing from mind }\end{array}$ & & & & 0.83 \\
\hline & & & Increased awareness & & & & 0.82 \\
\hline & & & Reaching deep meditating state & & & & 0.90 \\
\hline \multirow[t]{5}{*}{2} & Watching & the & Observe your breathing closely & 8.30 & 0.84 & 74.1 & 0.90 \\
\hline & $\begin{array}{l}\text { coolness in } \\
\text { nostril }\end{array}$ & the & $\begin{array}{l}\text { Focusing the attention on } \\
\text { coolness during breathing }\end{array}$ & & & & 0.82 \\
\hline & & & Control the thoughts & & & & 0.80 \\
\hline & & & Increased awareness & & & & 0.80 \\
\hline & & & Reaching deep meditating state & & & & 0.90 \\
\hline \multirow[t]{7}{*}{3} & Watching & the & Observe the breathing & 8.42 & 0.87 & 73.2 & 0.81 \\
\hline & Breathing & a & Watch the breath as if you are & & & & 0.85 \\
\hline & river & & watching a river & & & & 0.79 \\
\hline & & & Controlling the thoughts & & & & 0.80 \\
\hline & & & Thoughts will start settling down & & & & \\
\hline & & & Increased awareness & & & & 0.80 \\
\hline & & & Reaching deep meditating state & & & & 0.91 \\
\hline
\end{tabular}

Analysis and results: The data collected was analyzed by using SPSS 16th version. The results of the study were analyzed on the basis of descriptive statistics, multiple regression and correlations. The result of the study was analyzed on the basis of descriptive statistics, correlations and regressions.

Table No: 3 Correlation between Vipassana Meditation Process and Life effectiveness

\begin{tabular}{llll}
\hline $\begin{array}{l}\text { Analysis } \\
\begin{array}{l}\text { Independent Variable } \\
\text { Vipassana }\end{array}\end{array}$ & Watching the belly & $\begin{array}{l}\text { Watching the coolness } \\
\text { in the nostril }\end{array}$ & $\begin{array}{l}\text { Watching the } \\
\text { Breathing like a river }\end{array}$ \\
\hline Psychological & $0.366^{* *}$ & $0.359^{* *}$ & $0.333^{* *}$ \\
Physical & $0.392^{* *}$ & $0.341^{* *}$ & $0.321^{* *}$ \\
Professional & $0.356^{* *}$ & $0.329^{* *}$ & $0.332^{* *}$ \\
Managerial & $0.351^{* *}$ & $0.340^{* *}$ & $0.356^{* *}$ \\
\hline
\end{tabular}

${ }^{* *}$ Significance at 0.01 level)

The first Hypothesis (H1) indicates that 'Vipassana meditation process may significantly relate to the life effectiveness among business management graduates in their professional and personal life.' The findings (table no. 3) clearly indicates that there is positive correlation (significant at the 0.01 level) exists between 4 sub variables of Dependent Variable life effectiveness (viz., psychological, physical, professional and managerial,) with independent variable Vipassana meditation process viz., (3 sub variables of Vipassana meditation process). Hence, the study accepts the first hypothesis selected for the study. 
Table 4: Regression Analysis: Compensation factor and Coping Style Analysis Dependent Variable: Life effectiveness

\begin{tabular}{|c|c|c|c|c|}
\hline S/N & Dependent & $\begin{array}{l}\text { Watching } \\
\text { the } \\
\text { coolness in } \\
\text { the nostril }\end{array}$ & $\begin{array}{l}\text { Watching the } \\
\text { coolness in the } \\
\text { nostril }\end{array}$ & $\begin{array}{l}\text { Breathing } \\
\text { like a river }\end{array}$ \\
\hline 1 & Psychological & 0.699** & 0.680 ** & 0.700 ** \\
\hline 2 & Physical & $0.681^{* *}$ & $0.721 * *$ & $0.669 * *$ \\
\hline 3 & Professional & $0.711^{* *}$ & $0.697^{* *}$ & $0.721^{* *}$ \\
\hline 4 & Managerial & $0.700^{* *}$ & 0.711** & $0.720^{* *}$ \\
\hline
\end{tabular}

The major hypothesis stated includes 'Vipassana meditation process may significantly influence the life effectiveness of business management graduates in their professional and personal life. Multiple regression analysis (table no. 4) was used for examining whether each life style dimension is affected by 3 patterns of Vipassana Meditation process. All regression models are significant at the 0.01 level. Here the finding is in line with the second hypothesis stated in the paper. Thus, the second hypothesis stated is well accepted.

\section{Analysis on Socio demographic variables}

Table 5: Kruskal Wallis Test: Socio demographic factors influence on life effectiveness

\begin{tabular}{llllc}
\hline S/N & Socio demographic factors influence on coping & H Value & DF & Significance \\
\hline 1 & Economic condition and life effectiveness & 3.600 & 4.0 & 0.231 \\
2 & Age and life effectiveness & 3.679 & 4.0 & 0.434 \\
3 & Marital status and life effectiveness & 1.700 & 10.00 & 0.061 \\
4 & Year of experience and life effectiveness & 3.413 & 1.0 & 0.009 \\
5 & Gender and life effectiveness & 3.222 & 1.0 & $0.009^{* *}$ \\
\hline
\end{tabular}

The third hypothesis (H3) stated in this paper was "The socio-demographic (age, gender and employment) variables may have moderating effect on Vipassana Meditation process and life effectiveness of business management graduates in their professional and personal life." In order to test this hypothesis Kruskal Wallis Test was conducted. The analysis clearly indicates that out of the 5 socio demographic variables selected for the study, only one factor viz., gender (0.009) influence the life effectiveness. Hence the study partially only accept the hypothesis stated.

Discussion: The present study tries to establish the relationship between Vipassana Meditation practice and life effectiveness. The results indicate that the Vipassana Meditation Process helps in transforming the attitude of business management students in their personal and professional life. The research findings are in tune with the hypothesis stated in the research. Its influence is clearly visible with the evidence through the research on professional managers in corporate sector. Modern business life is moving in such a rapid pace that nobody have enough time to think of their quality of life. Managers carry their day to day activities looking at deadlines and targets. Managers get little space for introspection and self-improvement either in the profession or personal life. Just as preconditioned machinery, their life is moving on with predetermined script. In this context the present research findings gives a better insight into the improvement of life effectiveness, in general. Awareness about the self helps the professionals to reduce their stress at work place by undertaking the operations with calm, composed, focused, mentally alert, intellectually stimulated and mature outlook and behaviour. Vipassana Meditation Process helps to undergo this self-awareness process and helps the emerging professional to face the challenges and opportunities through positive outlook and matured behavior. In this context, Jayantilal (2003) rightly indicated that the Vipassana meditation technique improves the lives of executives and business managers by transforming their attitudes. Prejudice is replaced by compassion; jealousy changes into joy at the success of others; greed and arrogance are replaced by generosity and humility, and so on. This transformation of attitude results in stress reduction, 
and mental equanimity and balance. It is a creative force capable of inducing a dynamic work approach in subordinate staff. The positive change is brought about by a change in the attitude and actions of the executives-to be polite and compassionate behavior, gentle speech, and a mind full of love and friendliness.

This positive change in consciousness is the aim of genuine meditation practice, and it forms a new and advanced basis for business and industrial management. The result in correlation with the above discussion indicates that the junior level managers at various business operations who have undergone the Vipassana Meditation process tries to improve their life effectiveness through a balanced state of mind and awareness of their sensations. One should evaluate the importance of holistic curriculum in their contribution towards life effectiveness. The students, now they turned to be the managers, who got an opportunity to experience this self awareness process during their academic exposure or during habit moulding process, inculcated new values, mind set and a positive attitude towards personal and professional life, which support them to cope up with occupational stress with their own inner abilities and self awareness. Here the holistic education plays a bigger role, which incorporates the spiritual, physical, professional, psychological teaching and training in their regular academic curriculum. Attitude transformation is the most important challenge and the responsibility the students have to achieve during academic days from curriculum. Industry expects students with 'work values, work ability and work attitude'. When 'workability' blends with 'work attitude' among professionals, the result will be performance excellence and competency. Hence, a holistic education that incorporates the Vipassana Meditation process helps institutions to inculcate better attitude among business graduates so that they further contributes effectively business growth to industry.

This discussion is supported by the report of Jayantilal (2003), in relation to management profession that business management is presently judged by profits or "money-making" ability. Managers are evaluated by their ability to make more money by increasing product turnover, developing new technologies with better pay-offs, or decreasing costs through new inventions. In return, they want higher salaries and more requisites. Although there is nothing inherently wrong with generating profits and an increase in incomes, the real aim of an economic venture is to create a wealth, which combines money with health and happiness. Vipassana meditation makes a significant contribution towards improving the mental health and happiness of individuals-vital components of wealth. The finding of the present research indicates that the managers are well molded with better psychological, physical, professional and managerial attributes. The managers who attended the Vipassana meditation are well equipped to handle their professional personal life contribute more to their life effectiveness. The findings of the present research are more beneficial to Human Resource Development. This department is handling majority inter personal problems in industry. This department is dealing personal attributes of the managers during their recruitment and maintenance like anger, arrogance, jealousy, vengeance, selfishness, greed, prejudice and ill will and many other emotional-hostility factors. The Vipassana Meditation helps to control over the emotional imbalances and be self-controlled. Vipassana Meditation leads to better inter personal relationship, communication, teamwork, group work, mutual respect and group cohesiveness. In this framework Shah Jayantilal (2003) further, indicate that "one of the parameters in HRD process is the development of mutual respect, which naturally improves interpersonal relations. Meditation will also help to achieve this, enabling us to overcome the hostility towards fellow human beings- colleagues, subordinates, superiors, government officers and others. This hostility manifests as anger, arrogance, jealousy, vengeance, selfishness, greed, prejudice and ill will. Based on the finding it is inferred that Vipassana meditation is thus a scientific process of self-exploration: a system of selftransformation by self-observation, a healing by observation of and participation in the universal laws of nature. The study thus proves that the process of mind purification influences the attitude and behaviour of student's and it contributes to life effectiveness. The holistic education thus leads to matured and rationale behaviour and facilitate to better adjustment and coping with life events. It helps us to promote social wellbeing, self-development and leads to a happy life through continuous purification of the mind.

\section{Conclusion}

The above findings clearly indicates that Vipassana Meditation Process has high importance to get orient the students with better physique, psycho-social state that helps students and managers to become a professional with focused managerial aptitude. More awareness is to be made on Vipassana Meditation course to business schools, so that institutions can bridge the attitudinal gap between 'what personality of 
human being industry wants and what institutions now providing'. It is the responsibility of the institutions to inculcate better attitude and behavior through holistic education process so that quality students can be supplied to industry. Better life effectiveness and the quality of life is the byproduct of the Vipassana Meditation. New educational curriculum may consider its application to induct and orient students as quality human resource towards industry and society. More research in this area by including institutions from difference countries across the globe need to be explored further to generalise this findings.

\section{References}

Dhar, P. L. (2003). Holistic Education and Vipassana' Online Document. Citation URL: http://pldhar.wordpress.com/publications/ (Retrieved January 6 $6^{\text {th }}, 2006$ ).

Fleischman, P. R. (1986). The Therapeutic Action of Vipassana and Why I Sit, Buddhist Publication Society, Kandy, Sri Lanka.

Goleman, D. (1977). Meditation and Consciousness: An Asian Approach to Mental Health. Am. J. Psychother, $30,41-54$.

Jayantilal, S. (2003). Vipassana and Business Management Online document, 1-4. Citation: URL: www.vridhamma.org/Vipassana-and-Business-94-Seminar. (Retrieved January $6^{\text {th }}, 2006$ ).

Joshi, S. S. (2003). The Effect of Vipassana on the Work Environment, Vipassana Research Institute, Dhammagiri, Igathpuri: India, Online Document. Citation in: http://www.aygrt.net/PublishArticles/ 252.aspx. (Retrieved on April $9^{\text {th }}$ 2010).

Krishnamurti on Education, Krishnamurti Foundation, (1992). Holistic Education and Vipassana, Citation URL: www.vridhamma.org/Holistic-Education-and-Vipassana, (Retrieved January $6^{\text {th }}, 2006$ ).

Nichani, J. N. (2003). Vipassana Meditation and Health, Online Document. (Citation URL: www.vridhamma.org/Holistic-Education-and-Vipassana, (Retrieved January 6 ${ }^{\text {th }}, 2006$ ).

Thray, S., Sayagyi, U. \& Ba, K. (1983). The Essentials of Buddha Dhamma in Meditative Practice. Vipassana Journal, Hyderabad, India: Vipassana International Meditation Centre, 5, 1-6.

Usha, M. (2000). Vipassana: It is Relevance to the Individual and Society, Cited in Buddhism Today. Updated Online Document. http://www.vridhamma.org/Relevance-to-Individual-and-Society-94 (Retrieved on $21^{\text {st }}$ April, 2010).

Venerable, N. T. (1962). The Heart of Buddhist Meditation, Rider, London

Vipassana Research Institute (1989). A reader: Seminar on Vipassana Meditation for Relief from Addiction and Better Health, Nashik.

Vipassana Research Report, (2003). Psychological effects of Vipassana on Tihar jail inmate. Vipassana Research Institute, Dhamma Giri, Nasik, Maharashtra, India. 